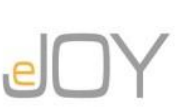

Öztek, M. Y., Yerden Karabıyık, N., Çolak, E., Sar1, E. / Journal of Yasar University, 2021, 16/62, 1053-1077

\title{
Fenomen Pazarlamasında Sosyal Medyanın Rolü ve Moda Sektörü Üzerine Bir İçerik Analizi
}

\section{The Role of Social Media in Phenomenon Marketing and a Content Analysis on Fashion Sector}

\author{
Mehmet Yaman ÖZTEK, Galatasaray Üniversitesi, Türkiye, moztek@gsu.edu.tr \\ Orcid No: 0000-0002-1129-5145
}

Nevin KARABIYIK YERDEN, Marmara Üniversitesi, Türkiye, nkarabiyik@marmara.edu.tr

Orcid No: 0000-0003-1114-2672

Ecenur ÇOLAK, Galatasaray Üniversitesi, Türkiye, ecenurclk@gmail.com

Orcid No: 0000-0002-6602-3227

Ecem SARI, Galatasaray Üniversitesi, Türkiye, ecemsari19@gmail.com

Orcid No: 0000-0003-2687-3400

\begin{abstract}
Öz: Dijitalleşmenin bir sonucu olarak sosyal medya insan hayatının vazgeçilmez bir parçası haline gelmektedir ve bu platformlardaki tutundurma faaliyetleri giderek artmaktadır. Sosyal medyada tutundurma araçlarından fotoğraf ve video paylaşma uygulaması olan Instagram üzerinden yapılan fenomen pazarlaması, özellikle de son yılların popüler ürün tanıtma araçlarından biri olmuştur. Bu bağlamda bu makalede Instagram üzerinden yapılan fenomen pazarlamasına ilişkin bir içerik analizinin yapılması amaçlanmıştır. Moda sektöründe en çok marka etkileşimi olan ve ürün tanıtımı yapan iki Türk ve iki yabancı fenomenin Ekim-Aralık 2019 tarihleri arasında paylaştıkları 601 gönderi, belirlenen 10 kritere göre incelenmiştir. Araştırmada ölçüt örnekleme yöntemi kullanılmıştır. Elde edilen sonuçlara göre çoğunlukla lüks modaya yönelik paylaşım yapan fenomenlerin paylaşımlarının \%64'ten fazlasının faaliyet alanları olan moda sektörüyle uyumlu olarak moda ürün tanıtımı içerdiği belirlenmiştir. Fenomenler ürün tanıtımlarını genellikle videoya kıyasla fotoğraf şeklinde, çoğunlukla klyafet ve yabancı kökenli marka tanıtımı olarak yapmaktadır. Fenomenler aynı zamanda tanıtılan ürünü, görsel içinde ön planda konumlandırmayı tercih etmektedir. Ayrıca çalışma sonucunda fenomenlerin tanıtımlarında ă̆ırlıklı olarak uzak çekimleri, görsel yoğunluk açısından sadeliği ve ürünleri, görselin merkezinde konumlandırmayı tercih ettikleri gözlemlenmiştir. Bu sonuçlar moda sektöründe fenomen pazarlamasında özellikle sadeliğin, uzak çekimlerin, ürün merkezli tanıtım çalışmalarının tercih edilmesi gerekliliğini ortaya koymaktadır.
\end{abstract}

Anahtar Kelimeler: Fenomen Pazarlaması, Sosyal Medya Siteleri, Sosyal Medya Pazarlaması, Instagram, Moda Sektörü

JEL Siniflandirmasi: M30, M31, M37, M39

Abstract: Social media has become an indispensable part of human life as a result of digitalization, and the promotional activities on these platforms have gradually increased. Influencer marketing through Instagram, which is an application for photo and video sharing, has been one of the popular tools for product promotion, especially in recent years. In this context, it is aimed to make a content analysis of influencer marketing on Instagram in this article. Between October and December 2019, 601 posts shared by two Turkish and two foreign influencers in the fashion industry with the most brand interaction and product promotion were analyzed according to 10 criteria. Criterion sampling method was used in the research. Results showed that more than $\% 64$ of mostly high fashion posting influencers' posts includes fashion product promotion in accordance with their profession the fashion sector. Influencers tend to do product promotions via photos rather than videos and mostly promote clothes and foreign brands. They also prefer to put the products to forefront. Moreover, it is observed that the influencers prefer distant shots, simplicity in visual density and central positioning for the products in their promotions. The brands promoted by influencers who mostly prefer advertisement in their promotions as a form of displaying products are listed in the results section of this article.

Keywords: Influencer Marketing, Social Media Sites, Social Media Marketing, Instagram, Fashion Sector

JEL Classification: M30, M31, M37, M39

Makale Gecmiși / Article History

Basvuru Tarihi / Date of Application

Kabul Tarihi / Acceptance Date

: 10 Ocak / January 2021

: 22 Şubat / February 2021 


\section{Giriş}

Dijitalleşmenin yaygınlaşması ile birlikte tüketiciler ve işletmeler arasındaki mesafe gittikçe azalmakta, taraflar birbirlerine bir "tık” kadar yakın hale gelmektedir. Tüketicilere geleneksel yollardan ulaşmak her geçen gün zorlaşmaktadır. Değişen tüketici tercihlerini ve beğenilerini karşılamak için işletmelerin de kendilerini tanıtma yöntemleri gün geçtikçe değişmektedir (Uydacı 2004, 83). Değişen tüketici trendi, dijital pazarlama çalışmalarından oldukça etkilenerek yeni tanıtım ve pazarlama yöntemlerini gerekli hale getirmektedir.

Dijital pazarlama, doğrudan pazarlamanın alıcı ve satıcıyı elektronik ortamda elektronik posta, internet sitesi, sosyal ağlar, çevrimiçi forumlar, televizyon veya mobil iletişim gibi interaktif teknolojik araçlar aracılığıyla bir araya getiren bir türü olarak tanımlanmaktadır (Purwar 2019, 992). Sosyal medya siteleri günümüzde en az geleneksel medya kadar hatta belki de daha etkili araçlar olarak görülmektedir (Close 2012, 83). Bu sebeple pazarlama faaliyetleri noktasında geleneksel medyanın yanı sıra sosyal medya platformları da yoğun şekilde kullanılmaktadır. İnternet, sosyal medya, mobil uygulamalar ve diğer dijital iletişim teknolojileri, dünya çapında milyarlarca insan için günlük yaşamın bir parçası haline gelmektedir. Ekim 2020 için son istatistiklere göre; 4,66 milyar kişi aktif internet kullanıcısıdır ve küresel nüfusun \%59'unu oluşturmaktadır. (Statista 2020a). Sosyal medya dünyadaki birçok insanın hayatının ayrılmaz bir parçası haline gelmiş durumdadır ve sosyal medya kullanan kişi sayısı hızla artmaktadır. 2020'de dünya çapında 3,6 milyar kişi aktif sosyal medya kullanıcısıyken, 2025 yılına kadar bu sayının neredeyse 4,41 milyara yükseleceği tahmin edilmektedir (Statista 2020b). Sosyal medyanın günümüzde iletişim kurma, bağlantı kurma ve etkileşim şeklini değiştirdiği görülmektedir (Cuevas, Chong ve Lim 2020, 1; Dwivedi vd. 2020).

Dijital ve sosyal medya ile birlikte reklamcılık ve tanıtım kampanyalarının daha interaktif ve katılımcı olduğu gözlemlenmektedir (Purwar 2019, 993). Bu araçlar sayesinde tüketiciler ile birebir iletişim kurularak pazarlama faaliyetlerinin yürütülmesi, hatta kişiselleştirilmiş ürün ve hizmetlerin sunulması mümkün olmaktadır (Kotler ve Armstrong 2011, 205). Dijital ve sosyal medya aracılığıyla yürütülen reklam faaliyetlerinin amacı da tıpkı geleneksel reklamlar gibi marka hakkında farkındalık oluşturmak, bilgi vermek, tüketiciyi ikna etmek, cesaretlendirmek ve bu sayede satış gerçekleştirmektir (Purwar 2019, 993).

Sosyal medya, en geniş kapsamda, bireylerin içerik oluşturup paylaştığı ve birbiriyle iletişim halinde olduğu web tabanlı bir oluşumdur (Sütçü vd. 2014, 877). Sosyal medya, sosyal etkileşimi sağlayan internet temelli uygulamalar ile çeşitli yöntemler bütününü ifade etmektedir. Hem işletmeler hem de tüketiciler blog veya halka açık siteler aracılığıyla sosyal medyada yer almaktadır. Sosyal medyada kullanıcılar tarafından oluşturulan içerikler kişiden 
kişiye etkileşim ile artmakta, yapılan konuşmalarla teşvik edilmektedir. Sosyal medya denilen bu çevrimiçi bölge; sosyal iş iletişimi, ağ oluşturma ve sosyal ticaretin yürütülebilmesi için bir platform sağlamaktadır (Collier 2012, 11). Tüketiciler, diğer tüketicilerle deneyimleri hakkında iletişim kurarak ve işletmelerle etkileşimli olarak ürün ve hizmetler hakkında bilgi aramak amacı ile çevrimiçi ortamlarda giderek daha fazla zaman harcamaktadır. İşletmeler ise dijital pazarlamayı ve sosyal medyayı, pazarlama planlarının ayrılmaz bir parçası haline getirerek değişen tüketici trendine yönelik çalışmalar gerçekleştirmektedir (Dwivedi 2020, 2). $\mathrm{Bu}$ değişim ise beraberinde sosyal iş biçimlerini ortaya çıkartmaktadır. Sosyal iş biçimi, işletmelerin faaliyet gösterme yöntemini kökten değiştirmekte ve bu sayede tüm taraflar için bir değer meydana getirmektedir. Yeni bir kavram olan sosyal iş biçimi, işletmelerin iç ve diş ilişkilerini dönüştürmekte, iç personeli dış tedarikçiye, bayiye ve tüketicilere bağlamakta, bu sayede taraflar arasında karşılıklı bir iş birliği meydana getirmektedir. Sosyal medya ticareti de bu bağlantı sürecinin en zorlu kısmı ve aynı zamanda para akışının sağlandığı noktada yer almaktadır. Sosyal medya ticareti, sosyal medya teknolojileri ve sosyal medya ağlarının ticaret yapmak amacıyla kullanılmasıdır. Sosyal medya kanalıyla işletmeler yeni ürünler hakkında farkındalık oluşturma, tüketicilere ürüne nasıl bakılacağını öğretme, tüketici yorumlarına göre yeni ürün hatları geliştirme ve satma, tüketici ihtiyaçlarına göre işi uyarlama, dönemsel indirimler ve pazarlama mesajlarının reklamını yapma ve tüketici hizmetleri vaatlerini yerine getirme gibi stratejiler uygulayabilirler (Collier 2012, 12).

$\mathrm{Bu}$ bağlamda, bu makalenin amacı dijitalleşme ile birlikte ortaya çıkan sosyal medya kanallarında, reklam ve tanıtım aracı olarak kullanılan fenomen pazarlamasına dair bir içerik analizi gerçekleştirmektir. Moda sektörü ile ilgilenen fenomenler üzerine yapılmış olan bu çalışmada, moda sektörü ve fenomen pazarlamasında en çok tercih edilen fotoğraf ve video paylaşım uygulaması olan Instagram üzerine yoğunlaşılmıştır. Çalışmada Instagram uygulamasında faaliyet gösteren ve moda sektöründe önde gelen fenomenlerden en çok marka etkileşimi bulunan iki Türk ve iki yabancı olmak üzere toplam dört kadın fenomen seçilmiştir. Fenomen pazarlamasının yurt içindeki ve yurt dışındaki uygulamalarının analiz edilebilmesi amacı ile seçilen iki Türk ve iki yabancı fenomenin paylaşımları analiz edilmiştir. Çalışmada seçilen dört fenomenin 2019 yılının Ekim, Kasım ve Aralık ayları olmak üzere üç aylık süreçteki ürün tanıtımını içeren paylaşımları analiz edilmiştir. Paylaşımlar; gönderi içeriği, ürün yerleştirme biçimi, ürün türü, marka kökeni, marka isimleri, görsel içindeki yer, görünürlük, kamera açısı, ürünün sergilenme biçimi ve görsel yoğunluk olmak üzere 10 ana başlık altında incelenmiştir. Çalışma sonucunda, seçilen Instagram fenomenlerinin belirli bir zaman diliminde ürün tanıtımı yaparken gösterdikleri eğilimler belirlenmeye çalışılmıştır. 


\section{Fenomen Pazarlaması}

Her geçen gün daha da önem kazanan sosyal medya, çevrimiçi pazarlama iletişimi açısından önemli bir platform haline gelmektedir. İşletmeler sosyal medya üzerinden yürüttükleri marka iletişimi çalışmaları çerçevesinde kurumsal hesaplar kullanmaktadır. Ayrıca işletmeler bazı durumlarda marka mesajlarının iletilmesi için belirli sosyal medya kullanıcıları ile iş birlikleri de yapabilmektedir (Sönmez ve Taşkıran 2019, 218). Günümüzde özellikle de Instagram’da sıklıkla karşılaşılan “influencer” kavramı Türkçe literatürde "fenomen”, "etkileyici”, "kanaat önderi" gibi farklı şekillerde yer almaktadır. Bu çalışmada ise "fenomen" kavramı kullanılmaktadır. Fenomenler "bir ürün veya konu hakkında belirli bir seviyede bilgi sahibi olan ve kitlelerin düşünce ve davranışlarını etkileme yeteneği bulunan kişiler” olarak tanımlanmaktadır (Armağan ve Doğaner 2018, 224). Ağızdan ağıza pazarlama iletişiminin geniş kitlelere yayılmasında önemli bir rol oynayan fikir liderleri, çevrimiçi kanallardaki fenomenler haline dönüşmektedir. Günümüzde fenomenler, kendilerini uzmanı olarak gösterdikleri belirli konularda, düzenli şekilde ilgi çekici içerikler üreterek adeta bir marka haline gelmektedir (De Veirman, Cauberghe ve Hudders vd. 2019, 801). Oldukça geniş bir takipçi kitlesi bulunan bu kişiler, marka ve ürünleri de dahil olmak üzere çeşitli konulardaki görüş ve deneyimlerini takipçilerine aktarmaktadır. Fenomenlerin sosyal medya üzerinden gerçekleştirdikleri bu pazarlama faaliyetleri çevrimiçi ağızdan ağıza pazarlama iletişimi ile sosyal medya sitelerinin bir araya gelmesi sonucunda ortaya çıkmakta ve "fenomen pazarlaması" adını almaktadır (Armağan ve Doğaner 2018, 225). Fenomenler her ne kadar günümüzde çalışmalarını yoğun bir şekilde Instagram, Facebook ve Youtube gibi sosyal medya siteleri üzerinden yürütseler de fenomenlik kavramının kökeni kişisel blog sitelerinde yaşam tarzlarını paylaşan ve bloglarında kullandıkları fotoğraflar için modellik yapan "bloggerlara" dayanmaktadır. Günümüzün fenomen pazarlaması kavramı, "bloggerlık" kavramının daha profesyonel bir şekilde yürütülen biçimi olarak görülebilir (Abidin 2016, 87).

Fenomenler, tüketicilere kıyasla daha profesyonel şekilde ağıdan ağıza pazarlama iletişimi kurmaktadır (Sudha ve Sheena 2017, 16). Fenomen pazarlaması temel olarak ürün ve marka hakkında bilgi vermek, tüketicilerin satın alma kararını etkilemek ve marka bilinirliğini artırmak amacıyla gerçekleştirilen faaliyetleri içermektedir. Fenomenler tarafından gerçekleştirilen ağızdan ağıza pazarlama iletişiminin gücü, fenomenin ilgili konudaki bilgi düzeyi ile doğrudan ilişkilidir. Fenomen kişinin konu hakkındaki bilgi düzeyi ne kadar yüksekse takipçilerine ileteceği mesaj o kadar etkili olmaktadır (Wiedmann, Hennigs ve Langner 2010, 145). Günümüzde markalar, iş birliği yapacakları fenomenleri takipçi kitlelerinin işletmenin hedef müşteri kitlesi ile uyumuna göre seçmektedir. Markalar 
genellikle bu iş birliğini ücretsiz hediye ürün göndererek veya fenomenlerle ödeme karşılığında çalışarak gerçekleştirmektedir. $\mathrm{Bu}$ çerçevede fenomen tanıttığı ürünün fotoğrafını, ürün özelliklerini ve ürüne yönelik önerilerini yazılı veya sözlü olarak paylaşmaktadır (Can ve Koz 2018, 453).

Business Insider'ın raporuna göre işletmeler tarafından fenomen pazarlaması için en çok tercih edilen platform \%79 oranıla Instagram olmuş, ardından \%46 ile Facebook ve \%36 ile YouTube gelmiştir (Business Insider 2020). Sudha ve Sheena gerçekleştirdikleri bir çalışmada fenomen pazarlamasını; kazanılmış fenomen pazarlaması ve ücretli fenomen pazarlaması olarak iki ayrı kategoride ele almıştı. Kazanılmış fenomen pazarlaması, marka tarafından herhangi bir ödemenin yapılmadığı ve genellikle fenomen kişinin kendi çıkarlarına yönelik içerik ürettiği bir pazarlama biçimidir. Ücretli fenomen pazarlaması ise sponsorluk, videodan önce gösterilen reklamlar veya referans mesajları şeklindeki içeriklerin sunulduğu bir pazarlama biçimidir ve işletmeler bu içerikler karşılığında fenomene belirli bir miktar ödeme yapmaktadır. (Sudha ve Sheena 2017, 16)

İşletmeler marka bilinirliğini ve reklam kampanyalarının etkinliğini artırmak, tüketicilerin ilgisini işletme ve ürünlerine çekebilmek için pazarlama faaliyetlerinde ünlü kişilerin kullanımını sıklıkla tercih etmekte ve bu durum literatürde "ünlü pazarlaması" olarak yer edinmektedir (Spry, Pappu ve Cornwell 2011, 883). Pazarlama faaliyetlerinde ünlülerin yer almasının markalar açısından birçok olumlu etkisi bulunmaktadır. Ancak günümüzde insanların fenomen olarak adlandırılan kişileri ünlülere kıyasla kendilerine daha yakın hissetmeleri, fenomenler aracılığıyla gerçekleştirilen pazarlama faaliyetlerinin ünlü pazarlamasına kıyasla tüketiciler tarafından daha samimi ve güvenilir olarak algılanmasına neden olmaktadır (Jin, Muqaddam ve Ryu 2018, 568). Ünlü pazarlaması ve fenomen pazarlaması arasındaki en temel fark, içerik üretimi sürecinde ünlülerin herhangi bir katkısı bulunmazken fenomenlerin bu süreci baştan sona kendilerinin yönetmesidir. Bir diğer fark ise fenomenlerin pazarlama faaliyetlerinde ağızdan ağıza pazarlama iletişimi yaratırken ünlülerin yer aldığı reklam kampanyalarının amacının yalnızca ünlü kişinin sahip olduğu şöhretten yararlanmak olmasıdır (Veissi 2017, 10). Günümüzde sadık bir niş takipçi kitlesine sahip fenomenlerin, pazarlamada etkili olduğu kanıtlanmış durumdadır ve birçok işletme tarafından sosyal medyada önemli bir pazarlama yöntemi olarak tercih edilmektedir. Fenomenin sadık bir takipçi kitlesinin bulunması ve bu kitlenin marka ile uyumlu olması oldukça önemlidir. Bir yapay zekâ yazılımı pazarlayan işletmenin, ürünlerini, tanınmış bir veri bilimci aracılığı ile tanıtması bu duruma örnek olarak verilebilir (Fertik 2020). Dolayısı ile buradaki en önemli konulardan biri de fenomenin, hedef pazar ve marka ile uyumudur.

Günümüzde Facebook, Twitter, YouTube ve Instagram gibi internet kullanıc1ları 
tarafından en çok tercih edilen sosyal ağ siteleri üzerinden faaliyetlerini yürüten fenomenlerin takipçilerine görüş ve deneyimlerini aktardıkları kategoriler arasında seyahat, kozmetik, sağlıklı yaşam, teknoloji ve moda kategorileri ön plana çıkmaktadır (Örs 2018, 189). Bu nedenle yapılan çalışmada, ön plana çıkan kategorilerden biri olan moda sektöründeki fenomenlerin paylaşımları incelenmiştir.

Childers, Lemon ve Hoy yürüttükleri çalışmada Amerikan profesyonel reklam ajansı çalışanları ile yaptıkları görüşmeler sonucunda fenomen pazarlamasının hedef müşteri kitlelerine ulaşmak adına hem küçük hem de büyük markalar tarafından yaygın şekilde benimsendiğini belirtmektedir. Yazarlar ayrıca çalışmada reklam ajanslarının, fenomen pazarlamasının faydalarının farkında olduğunu ancak bu yeni pazarlama sürecinin nasıl yürütülmesi gerektiğine dair yeterince bilgi sahibi olmadıkları için geleneksel modelleri fenomen pazarlaması sürecine uyarlamaya çalıştıklarını da vurgulamaktadır (Childers, Lemon ve Hoy 2019). Bununla birlikte yapılan bir başka araştırma ise pazarlama uzmanlarının yaklaşık \%75'inin, ürünleri ve markaları hakkında sosyal medyada ağızdan ağıza pazarlama çalışmalarının yayılması için sosyal medya fenomenleri ile çalıştığını göstermektedir (Vyatkina, 2020, 1307).

Fenomenler sosyal ağ sitelerinde sahip oldukları takipçi sayılarına göre makro ve mikro fenomenler olarak iki ana başlık altında incelenmektedir. Bu yaklaşımda takipçi sayısı 100.000 kişinin altında olan fenomenler mikro fenomen kategorisine girerken, takipçi sayısı 100.000 kişinin üzerinde olan fenomenler makro fenomen kategorisinde değerlendirilmektedir (Aktaş ve Şener 2019, 406). Vyatkina'ya göre sosyal medya fenomenleri dört kategoride, Campbell ve Farrell göre ise beş kategoride sinıflandırılmaktadır. Cambell ve Fafell'in sinıflandırılması, Vyatkina'nın sınıflandırılmasını kapsamaktadır. Bu sebep ile aşağıda beş kategoriye göre gerçekleştirilen sınıflandırmanın detayları sunulmuştur (Vyatkina 2020, 1308; Campbell ve Farrell, 2020, 471-472):

1. Ünlü Fenomenler: 1 milyondan fazla takipçisi olan kişilerdir. Gerçek dünyadaki geçmişleri nedeniyle genellikle ünlüdürler. Erişimleri, marka bilinirliğini artırmak için kullanılır (Vyatkina 2020, 1308). Selena Gomez, Paris Hilton ve Kim Kardashian gibi büyük takipçi kitleleri olan kişilerdir. Bu kişiler tanınmış markalar ile önemli sözleşmeler yaparak çalışırlar (Campbell ve Farrell 2020, 471).

2. Mega Fenomenler: 1 milyondan fazla takipçisi olan ve sosyal medya aracıllı̆g ile ünlü olmuş kişilerdir (Vyatkina 2020, 1308). Ünlü fenomenlerin aksine, mega fenomenler marka tanıtımında genellikle ücretli ortaklık anlaşması yaparlar (Campbell ve Farrell 2020, 472).

3. Makro Fenomenler: 100.000 ile 1 milyon arasında takipçisi olan fenomenlerdir. 
Öztek, M. Y., Yerden Karabıyık, N., Çolak, E., Sarı, E. / Journal of Yasar University, 2021, 16/62, 1053-1077

Özellikli bir pazarda yüksek etki gücüne sahiptirler. Aynı zamanda içerik kalitesi yüksek ve marka iş birliklerine açık olan kişilerdir (Vyatkina 2020, 1308). Bu fenomenler; gezi, yemek, müzik gibi belirli bir konuda uzmandır (Campbell ve Farrell 2020, 472).

4. Mikro Fenomenler: 1.000 ile 100.000 takipçisi olan fenomenlerdir. Takipçi sayısı az olsa da özgünlükleri yüksektir. Küçük ama sadık bir kitle, bu tür fenomenlere yüksek düzeyde güven ve katılım sağlar. Bazı durumlarda markaların birkaç mikro fenomen ile reklam yapması, ünlüler ile reklam yapmasından daha karlı olabilmektedir (Vyatkina 2020, 1308).

5. Nano Fenomenler: 1.000 'den az takipçisi olan ve özel bir toplulukta önemli bir etkiye sahip olan fenomenlerdir. Örneğin, bir nano fenomen, belirli bir mahallede, kurumda, toplulukta en güvenilir olan kişi olabilir. Reklamları, dostça bir tavsiyeye benzediğinden en yüksek etkileşim düzeyine sahip olabilmektedir (Vyatkina 2020, 1308).

$\mathrm{Bu}$ çalışmada incelenen dört fenomen, takipçi sayılarının 100.000 ile 1 milyon kişi arasında olması, sadece sosyal medyada bilinilirliklerinin bulunması ve belirli bir konuda uzmanlaşmış olmaları nedeniyle makro fenomen kategorisine girmektedir. Bireyler, fenomen kavramını çoğunlukla bir kişinin popülerlik düzeyi ile ilişkilendirmektedir. Ancak fenomenler yalnızca sosyal medya sitelerinde geniş takipçi kitlesine sahip olan kişiler olarak sınırlandırılmamalıdır. Belirli bir alanda saygınlığa, bilgi ve yeteneğe sahip olan kişiler de birer fenomen sayılmaktadır (Purwaningwulan vd. 2018, 116)

Sarıtaş 'in yürüttüğü çalışmada sosyal medyayla en çok etkileşime sahip olan genç nesil ile derinlemesine görüşmeler yapılmıştır. Yazar bu görüşmeler sonucunda katılımcıların birçoğunun sosyal medya reklamlarından rahatsızlık duyduğunu, ancak bu reklamların fenomenler tarafından gerçekleştirildiğinde kişilerin söz konusu reklama daha 1lımlı şekilde yaklaştığını keşfetmiştir. Sarıtaş, aynı zamanda fenomen pazarlamasının bireylerde marka farkındalığ 1 oluşturulmasında önemli olduğunu belirtmekte ve fenomenlerin önerdiği marka ve ürünlerin bazı bireylerde ilgi ve ürün hakkında bilgi toplama isteği uyandırdığını ifade etmektedir (Sarıtaş 2018, 73). Bu bulgular Çetin ve Öziç'in çalışmasıyla da uyumludur. Yazarlar, tüketicilerin sosyal medya siteleri üzerinde karşılaştıkları profesyonel kişiler tarafindan oluşturulan içeriklerden ziyade fenomenlerin hazırladığı içeriklerden daha çok etkilendiğini ortaya koymaktadır (Çetin ve Öziç 2020, 169). Z Kuşağı üzerinde yapılan bir başka araştırmaya göre, katılımcıların geleneksel ünlülerin kullanıldığı geleneksel reklamlara kıyasla sosyal medya fenomenlerinden etkilendiği ve işletmelerin bu hedef müşteri grubuna ulaşması için sosyal medya fenomenlerini tercih etmeleri önerilmektedir (Gümüş 2020, 394). 
Fenomen ve takipçileri arasındaki güven duygusu güçlü olduğunda, kişilerin takip ettikleri fenomenin ilettiği mesajlara karşı şüpheci yaklaşma ve bu mesajlardan kaçınma davranışı gösterme ihtimali düşük olmaktadır (Şener, Öztürk ve Suher 2019, 416). Günümüzün dijital dünyasında markaların fenomenler ile gerçekleştirdikleri iş birliklerinin sayısı her geçen gün daha da artmaktadır. Günlük hayatlarında oldukça yoğun şekilde fenomen pazarlaması örneği ile karşılaşan bazı tüketiciler bu içeriklere şüpheyle yaklaşmaktadır (Mashhadani 2019, 48). Ayrıca fenomenlerin ürün tanıtımı karşılığında markalardan belirli bir ödeme almaları, tüketicilerde fenomenin yalnızca para karşılığında ürünü önerdiği algısının oluşmasına neden olabilmektedir (Woods 2016, 8). Lou ve Yuan'a göre fenomenler tarafından oluşturulan içeriklerin bilgilendirici niteliğinin ve fenomenin güvenilirlik ve takipçileri ile olan benzerlik derecesinin müşteri güveni üzerinde olumlu bir etkiye sahip olduğu ortaya koyulmaktadır (Lou ve Yuan 2019, 71).

\subsection{Literatür Taramast}

Fenomen pazarlaması kavramına yönelik araştırmaların literatürde yakın zamanda başladığı görülmektedir. Öte yandan fenomen pazarlaması kavramı literatürde farklı isimler ile yer almaktadır. Aşağıdaki tabloda takipçi ile iletişimin satın alma kararına etkisi, sosyal medyanın reklam sektörüne etkisi, sosyal medya içeriklerindeki mesaj stratejileri, tüketicilerin tutumları, geleneksel medya ünlüleri ile fenomenlerin karşılaştırılması, müşteri güveni ve fenomen pazarlamasının etkinliği, marka tercihi, takipçi sayısı ve aykırı ürünlerin marka tutumuna etkisi gibi 2017 ile 2020 yılları arasında yapılmış araştırmalar yer almaktadır.

Tablo 1. Literatür Taraması

\begin{tabular}{|c|c|c|}
\hline Calısmavı Yapan & Çalışmanın Konusu & Çalışmanın Bulguları \\
\hline $\begin{array}{l}\text { De Veirman, } \\
\text { Cauberghe ve } \\
\text { Hudders, } 2017\end{array}$ & $\begin{array}{l}\text { Instagram fenomenlerinin takipçi } \\
\text { sayıları ile aykırı ürünlerin marka } \\
\text { tutumları üzerindeki etkileri }\end{array}$ & $\begin{array}{l}\text { Tüketicilerin, takipçi sayısı yüksek olan } \\
\text { Instagram fenomenlerini popüler ve etkili fikir } \\
\text { liderleri olarak gördüğ̈ için bu kişilere daha } \\
\text { olumlu yaklaştığı tespit edilmiştir. Bununla } \\
\text { birlikte çalışmada aykırı ürünlerin yüksek } \\
\text { takipçili fenomenler tarafindan pazarlanmasının } \\
\text { markanın algılanan benzersizliğini ve marka } \\
\text { tutumlarını olumsuz } \\
\text { vurgulanmıştır. }\end{array}$ \\
\hline Sarıtaş, 2018 & $\begin{array}{c}\text { Tüketicilerin, markalar ve } \\
\text { fenomenler tarafından yapılan } \\
\text { reklamlara yöneliktutumlarının } \\
\text { karş1laştırılması }\end{array}$ & $\begin{array}{l}\text { Genç neslin sosyal medya reklamlarından } \\
\text { rahatsız olduğu ve reklamı yalnızca kişinin ilgi } \\
\text { alanına hitap ettiğinde izlediği keşfedilmiştir. } \\
\text { Sosyal medya üzerinden fenomenler tarafindan } \\
\text { yapılan reklamlara yönelik tüketici tutumlarının } \\
\text { daha 1lımlı olduğu belirlenmiştir. }\end{array}$ \\
\hline $\begin{array}{l}\text { Armağan ve Doğaner, } \\
2018\end{array}$ & $\begin{array}{l}\text { Tüketicilerin Youtube'daki } \\
\text { kozmetik fenomenlerineyönelik } \\
\text { tutumları ve fenomenlerin } \\
\text { tüketicilerin satın alma } \\
\text { davranışları üzerindeki etkileri }\end{array}$ & $\begin{array}{l}\text { Tüketicilerin bir fenomene karşı tutumu ve } \\
\text { fenomen ile olan uzaklık/yakınlık derecesinin } \\
\text { satın alma davranışları ile anlamlı bir ilişkiye } \\
\text { sahip olduğu keşfedilmiştir. Ayrıca araştırmada } \\
\text { video karakteristiğine yönelik tutumun diğer } \\
\text { yaş gruplarına kıyasla } 25 \text { yaş ve altındaki } \\
\text { izleyiciler için daha güçlü olduğu ortaya } \\
\text { çıkmıştır. }\end{array}$ \\
\hline
\end{tabular}




\begin{tabular}{|c|c|c|}
\hline Aktaş ve Şener, 2019 & $\begin{array}{l}\text { Fenomenlerin sosyal medyada } \\
\text { ürettikleri içeriklerde } \\
\text { kullandıkları mesaj stratejileri }\end{array}$ & $\begin{array}{l}\text { Araştırmada makro fenomenlerin çoğunlukla } \\
\text { dönüşümsel mesaj stratejilerini tercih ettiği ve } \\
\text { içeriklerinde duygusal çekicilik unsuruna } \\
\text { odaklandıkları keşfedilmiştir. }\end{array}$ \\
\hline $\begin{array}{l}\text { Childers, Lemon ve } \\
\text { Hoy, } 2019\end{array}$ & $\begin{array}{l}\text { Dijitalleşme ve sosyal medyanın } \\
\text { yükselişinin reklam sektörü } \\
\text { üzerindeki etkileri }\end{array}$ & $\begin{array}{l}\text { Araştırmada reklam sektörünün fenomen } \\
\text { pazarlamasıı yaygın şekilde benimsediği } \\
\text { ancak sektörde sürecin nasıl yürütülmesi } \\
\text { gerektiği hakkında yeterince bilgi sahibi } \\
\text { olunmadığı keşfedilmiştir. }\end{array}$ \\
\hline $\begin{array}{l}\text { Jin, Muqaddam ve } \\
\text { Ryu, } 2019\end{array}$ & $\begin{array}{c}\text { Geleneksel ünlülerin ve } \\
\text { Instagram ünlülerinin tüketicilerin } \\
\text { kaynak güvenilirliği algısı ve } \\
\text { marka tutumları üzerindeki } \\
\text { etkileri. }\end{array}$ & $\begin{array}{l}\text { Çalışmada tüketicilerin ünlülere kiyasla } \\
\text { fenomenler tarafindan oluşturulan marka } \\
\text { gönderilerinde kaynağ } 1 \text { daha güvenilir olarak } \\
\text { aldıkları ve marka tutumlarının daha olumlu } \\
\text { olduğu belirtilmiştir. }\end{array}$ \\
\hline Lou ve Yuan, 2019 & $\begin{array}{l}\text { Müşteri güveni ile Fenomen } \\
\text { Pazarlaması etkinliğinin ilişkisi }\end{array}$ & $\begin{array}{l}\text { Çalışmada fenomenler tarafindan oluşturulan } \\
\text { içeriklerin bilgilendirici niteliğinin, fenomenin } \\
\text { takip kitlesi ile benzerlik derecesinin ve } \\
\text { fenomenin takipçileri tarafından algılanan } \\
\text { güvenilirliği ile çekiciliğinin müşteri güveni } \\
\text { üzerinde olumlu bir etkiye sahip olduğu } \\
\text { keşfedilmiştir. Ayrıca bu faktörlerin marka } \\
\text { bilinirliğini ve satın alma niyetini artırdığ1 } \\
\text { ortaya konmuştur. }\end{array}$ \\
\hline $\begin{array}{c}\text { Sönmez ve Taşkıran, } \\
2019\end{array}$ & $\begin{array}{l}\text { Sosyal medya fenomenlerinin } \\
\text { tüketicilerin marka tercihleri } \\
\text { üzerindeki etkileri }\end{array}$ & $\begin{array}{l}\text { Çalışma sonucunda sosyal medya } \\
\text { fenomenlerinin tüketicilerin marka tercihleri } \\
\text { üzerinde olumlu bir etkiye sahip olmadığ ve } \\
\text { tüketicilerin fenomenler tarafindan oluşturulan } \\
\text { içerikleri güvenilir olarak algılamadıkları } \\
\text { keşfedilmiştir. }\end{array}$ \\
\hline Çetin ve Öziç, 2020 & $\begin{array}{l}\text { Instagram fenomenlerinin } \\
\text { takipçileri ile sahip oldukları } \\
\text { iletişimin tüketicilerin satın alma } \\
\text { karar süreci üzerindeki etkileri }\end{array}$ & $\begin{array}{l}\text { Katılımcıların satın alma kararları öncesinde } \\
\text { fenomenlerin oluşturdukları içerikleri } \\
\text { inceledikleri ancak satın alma aşamasına } \\
\text { geldiklerinde bu içerikleri dikkate almadıkları } \\
\text { gözlemlenmiştir. }\end{array}$ \\
\hline
\end{tabular}

Fenomen pazarlamasına yönelik yapılan literatür taramasında fenomenlerin markalar ile etkileşiminin ve tüketici satın alma karar sürecindeki rolünün ön planda olduğu görülmektedir. Yapılan araştırmalar incelendiğinde fenomenlerin, marka tanıtımları yolu ile tüketiciler üzerinde ekili olduğu, bu sebep ile birçok işletmenin marka tanıtımlarında hedef kitlelerine uygun olarak fenomenleri tercih ettiğini söylemek yanlış olmayacaktır. Aynı zamanda yapılan bu araştırmalarda marka-fenomen-hedef kitle uyumu özellikle vurgulanmaktadır. Fenomen ve hedef kitleyle uyumlu olmayan bir markanın, bu yöntem ile başarı elde etmesi çok mümkün görünmemektedir.

\section{Sosyal Medya Pazarlaması}

Sosyal medya tüzel veya gerçek kişiler arasında sosyal etkileşimi sağlayan internet üzerindeki siteler, platformlar veya uygulamalardan oluşmaktadır (Collier 2012, 11). Robson ve Zachara sosyal medyayı kısaca haber, fotoğraf, video ve yayınların kamuya açık şekilde paylaşıldığı katılımcı çevrimiçi medya olarak tanımlamaktadır. Yazarlar sosyal medyanın kapsamlı tanımını ise "insanları içerik okuyucusundan içerik yayıncısına dönüştüren, bilginin demokratlaşması; yayın mekanizmasından 'çoktan çoka' modeline geçişi içeren, yazar, birey ve akranlar arasındaki konuşmalara dayanan platform" şeklinde yapmaktadır (Robson ve 
Zachara 2014). Buna göre sosyal medya aracılığıyla bilgi, "kalabalıkların bilgeliğì" anlayış1 temelinde ve iş birliği çerçevesinde yayılmaktadır. Sosyal medya bünyesinde, internet forumları, mesaj panoları, internet günlükleri, yayınlar, fotoğraflar ve videolar gibi çeşitli biçimdeki içerik ve platformları barındırmaktadır. Günümüzde yoğun olarak kullanılan başlıca sosyal medya platformları; sosyal ağ sitesi Facebook, fikir paylaşım sitesi Twitter, fotoğraf ve video paylaşım sitesi Instagram ve video paylaşım sitesi YouTube olarak bilinmektedir (Hemann ve Burbary 2013, 15).

İşletmeler sayılan tüm sosyal medya platformları üzerinden olası tüketicilerle iletişime geçebilir, onları markadan haberdar etmek, bilgilendirmek ve kazanmak amacıyla çeşitli faaliyetler yürütebilirler. Hatta işletmelerin radyo, televizyon veya dergi gibi geleneksel medya kanalları üzerinden yaptığı reklam ve tanıtımlarda kendi Facebook, Instagram, Twitter, YouTube veya diğer sosyal medya platformlarına yer vermeleri sosyal medya pazarlamasının bir örneği olarak görülebilir. Buna ek olarak işletmelerin bu sosyal medya platformları üzerinden yürüttüğü tüm pazarlama faaliyetleri de sosyal medya pazarlamasının kapsamına girmektedir. Sosyal medya insanlara birbirleriyle iletişim kurabilecekleri, hayatlarındaki önemli an ve bilgileri paylaşabilecekleri adeta dijital bir ev sunmaktadır. Sosyal medya sayesinde insanlar markalar hakkında konuşma firsatı bulmakta, bu da işletmelere "marka bilinirliği ve müşteri sadakati oluşturmak için imkân tanımaktadır. Dolayısıyla sosyal medyanın etkin ve doğru şekilde kullanılması işletmelerin marka değerine katk1 sağlamaktadır (Kotler ve Armstrong 2011, 20).

Sosyal medya pazarlamasında öne çıkan ve makalede ele alınan platform olan Instagram, 2010 yılında üyelerin fotoğraf ve video paylaşması amacıyla kurulmuştur. Öte yandan üyeler Instagram'ı diğer kişilere ilişkin bilgi aramak, ilgi alanlarını paylaşmak, hayatlarını belgelemek ve "diğer üyelere ne kadar havalı ve yaratıcı olduklarını göstermek" amacıyla da kullanmaktadır (Teo vd. 2018, 322). 2019 y1lı verilerine göre 855 milyon Instagram kullanıcısı bulunmaktadır ve bu sayının 2023 yılında 988 milyona ulaşması beklenmektedir (Statista 2020c). Kullanıcıların diğer sosyal medya platformlarına kıyasla Instagram'da daha fazla zaman harcamaları, bu platformu, sosyal medya pazarlamasına oldukça uygun bir mecra haline getirmektedir (Khan 2018, 120).

Weinberg'e göre sosyal medya pazarlaması; “ürün ve hizmetlerin çevrimiçi sosyal kanallar vasıtasıyla pazarlanması ve geleneksel tutundurma yöntemleriyle ulaşılamayacak kadar geniş tüketici kitleleriyle iletişime geçilmesini” ifade etmektedir (Weinberg 2009, 3). Sosyal medya pazarlamasının bir diğer tanımı Tuten tarafından "işletme hedeflerine ulaşmak ve işletmenin marka değerini artırmak amacıyla haber ve fikir paylaşım siteleri gibi çeşitli sosyal ağlar yoluyla kitlelere ulaşılmasını sağlayan çevrimiçi reklam biçimi” şeklinde 
yapılmaktadır (Tuten 2008, 19). Özgen ve Doymuş sosyal medya pazarlamasını "sosyal medya platformları aracılığlyla işletmeyi internette daha görünür kılmak ve ürün ile hizmetleri tutundurmak” şeklinde tanımlamaktadır (Özgen ve Doymuş 2013, 95). Bir başka araştırmada ise sosyal medya pazarlamasının beş amacı; tüketiciyle ilişki kurmak, marka inşa etmek, işletmeyi tanıtmak, indirim ve kampanyalardan haberdar etmek ve pazar araştırması yapmak şeklinde açıklanmaktadır. (Mohammadian ve Mohammadreza 2012, 59).

Sosyal medya pazarlaması günümüzde geniş kitlelere hitap etme kapasitesi, karşılıklı etkileşim imkânı, düşük maliyet, faaliyetlerin anlık yapılabilmesi ve hedef kitleye kolayca ulaşılması özelliklerinden ötürü tercih edilmektedir. Sosyal medya pazarlamasında kullanılan içerikler, bu mecralarda bulunan geniş tüketici kitlelerine hitap edecek şekilde anlık ve doğal olarak ortaya çıkarılmaktadır. Geleneksel ve ücretli reklamlara kıyasla sosyal medya platformlarında yer alan içerikler yalnızca işletmenin ticari çıkarlarına yönelik değildir. $\mathrm{Bu}$ içerikler aynı zamanda tüketiciyi markadan haberdar etme, bilgilendirme ve marka bilinirliğini artırma amaçlarını gütmektedir. Sosyal medya pazarlaması, etkin ve doğru kullanıldığı takdirde işletmeler ve tüketiciler arasında güçlü ilişkiler kurulmasını sağlamaktadır (Kotler ve Armstrong 2011, 508-515).

Sosyal medya pazarlamasında bir diğer önemli nokta sosyal medya metrikleridir. Sosyal medya metrikleri işletmelerin sosyal medyada aldığ 1 beğeni, takip, yorum ve tıklanma gibi etkileşimlerine bakılarak toplam etkilerinin ölçülmesi anlamına gelmektedir. Bu metrikler bakılan sosyal medya platformuna göre değişiklik göstermektedir. Örneğin Facebook’ta arkadaş sayısı, beğeni ve yorum gibi metrikler bulunuyorken, Instagram'da takipçi sayısı, beğeni, yorum, görüntüleme, kaydetme, başkalarına gönderme gibi farklı metrikler yer almaktadır (Marwick 2015, 75). Ölçülecek metriklerin doğru seçilmesi, ölçümün doğru yapılması ve sonuçların yorumlanarak pazarlama programının şekillendirilmesi işletmenin başarısı açısından son derece önemlidir. Bu metrikler Cymfony, Net Promoter, BlogPulse, Feedburner, Nielsen Buzzmetrics, Google Alerts, Blogsearch, EdgeRank Checker, PeerIndex, Brand 24, Google Trends, HowSociable, IceRocket, IFTTT, Social Mention, Sprout Social, TalkWalker Alerts ve WhosTalking.com gibi aracılar vasıtasıyla hesaplanabilir (Collier 2012, 132-247; Evans 2008, 142-144; Hemann ve Burbary 2013, 141-149; Zimmerman ve Ng 2017, 120-124). Ölçülen metriklerin doğru şekilde kullanılması için önce işletmenin amaçları tanımlanmalı, ardından standartları belirlenmeli ve elde edilen metrikler doğrultusunda işletmeye bir yol haritası çizilmelidir (Sterne 2010, 11-13; Booth ve Koberg 2012, 65-66).

Sosyal medya platformlarından Instagram'da yürütülen pazarlama faaliyetlerinin markaya sağladığı katkılar incelendiğinde çeşitli sonuçlar ortaya çıkmaktadır. Tack, Veirman ve Hudders, sosyal medya pazarlama faaliyetlerini Kim ve Ko'nun kavramsal çerçevesinde 

eğlence, etkileşim, modaya uygunluk, kişiselleştirme ve ağızdan ağıza pazarlama olmak üzere beş boyutta incelemektedir. Buna göre modaya uygunluk, eğlence ve ağızdan ağıza pazarlamanın "müşteri marka değerini” pozitif yönde etkilediği tespit edilmiştir. Eğlence ve ağızdan ağıza pazarlamanın satın alma niyetini artırdığı gözlemlenirken, modaya uygunluğun ise satın alma niyeti üzerinde olumsuz etkisi bulunduğu ortaya koyulmaktadır(Kim ve Ko, 2012). Sonuç olarak Tack, Veirman ve Hudders, lüks markaların Instagram'a yatırım yapmasının müşteri marka değeri ve dolayısıyla satın alma niyeti üzerinde olumlu etkiye sahip olduğunu savunmaktadır (Tack, Veirman ve Hudders 2020, 6768).

Instagram'daki marka kişiliğine ilişkin başka bir çalışmada markaların paylaşımlarında yansıttığı marka kişilikleri ile tüketicilerin algısının uyumlu olduğu tespit edilmiştir. Öte yandan yine aynı araştırmada Instagram'ın halkla ilişkiler amaçlı kullanılamadığı ve takipçilerle yeterli etkileşimin sağlanamadığı görülmüştür. Çalışmanın sonucunda markaların Instagram'da kişiliklerini yeteri kadar yansıtamadığı ortaya koyulmuştur (Garip 2019, 21). Bir diğer çalışmada tüketicilerin yüksek sokak modası perakendecilerine yönelik algı ve davranışlarının birçok iç ve dış faktörden etkilendiği, sosyal medya kullanımının da bu etkileri kolaylaştırdığı tespit edilmiştir. Buna göre sosyal medya, tüketicilerin satın alıma karar sürecindeki tek etkili faktör olmasa da sosyal medyanın kullanımının gittikçe yaygınlaşması bu süreçteki etkisini giderek artırmaktadır. Kişiler sosyal medyayı yüksek sokak modası perakendecilerine ilişkin ilham ve bilgi almak için aktif olarak kullanmaktadırlar (Nash 2019, 95-96). Khan ise Instagram pazarlamasının tek başına marka bilinirliği oluşturma ve yeni tüketicilere ulaşma aracı olarak düşünülmemesi gerektiği sonucunu ortaya koymaktadır. Çalışmada Instagram'ın gittikçe önemi artan ciddi bir marka imajı oluşturma aracı olduğu vurgulanmaktadır. Öte yandan çalışmada hem çevrimiçi hem de çevrimdışı kanallarda yapılan marka değeri yatırımlarının Instagram pazarlamasının tüketici yanıtları üzerindeki etkisini de artıracağı saptanmaktadır (Khan 2018, 122).

Kişilerin Instagram'1 kullanma motivasyonlarının araştırıldığı bir çalışmada, toplam 9 faktör belirlenmiştir. Buna göre sırasıyla eğlence/alışkanlık, sosyal kaçış/rahatlama, karar verme/bilgilenme, kişisel gelişim/kendini ifade etme, arkadaşlık, sosyal etkileşim, ekonomi, takip etme ve kişisel sunum faktörleri bireyleri Instagram kullanmaya yöneltmektedir. $\mathrm{Bu}$ faktörler cinsiyetlere göre incelendiğinde kadınların erkeklere kıyasla eğlence/alışkanlık ve karar verme/bilgilenme faktörlerine daha fazla önem verdiği tespit edilmiştir (Yayla 2018, 6162). Instagram kullanıcılarının satın alma davranışlarını inceleyen bir diğer araştırmada, kadınların, erkeklere göre daha fazla Instagram üzerinden alışveriş yaptıkları belirlenmiştir. Araştırmanın sonucunda katılımcıların bir işletmeyi takip etme amacının işletme 
ve ürünler hakkında bilgi almak olduğu ortaya çıkmaktadır. Ayrıca katılımcılar çoğunlukla kıyafet, ayakkabı, aksesuar ve saat kategorisindeki ürünleri satın almaktadır (Yaşa Özeltürkay, Bozyiğit ve Gülmez 2017, 193).

Tüketicilerin Instagram kullanımı ve satın alma davranışlarını inceleyen bir başka araştırmada katılımcıların, Instagram'da bulunan işletme sayfalarının paylaşımlarını ilgi çekici bulduğu, ürünlerin takip edildiği, ürünlerin satın alındığı, bilgi edinildiği, uygun fiyatlı ürünler bulunduğu ve güvenle alışveriş imkânı sunduğu için takip ettikleri saptanmıştır. Öte yandan katılımcıların Instagram üzerinden sırasıyla kıyafet, ayakkabı, aksesuar, hediyelik/süs eşyası, elektronik ve kozmetik ürünlerini satın aldığı ve katılımcıların bu yolla alışveriş yapma sebeplerinin uygun fiyatlı ürün bulunması, ürün çeşitliliğinin genişliği, alışveriş kolaylığı, güven ve kapıda ödeme imkânı olduğu tespit edilmiştir (Yılmazsoy 2019, 56). Sosyal medyada içerik üretimine ilişkin bir makalede, markaların sosyal medya paylaşımları üzerinden rakiplerini analiz edebileceği belirtilmiştir. Böylece markaların kendi içeriklerini geliştirip zenginleştirerek rakiplerinden farklılaşabilecekleri savunulmaktadır. Bu bağlamda markaların sosyal medyada tüketicilerin sorunlarını dinleyip çözerek, sosyal medya diline uyum sağlayarak, şeffaf olarak ve fotoğraf/video içerikleriyle tüketiciyi tatmin ederek başarılı olabilecekleri bildirilmektedir (Özgen ve Doymuş 2013, 101-102).

Akıncı Vural ve Okmeydan, çalışmalarında moda markalarının sosyal medyayı kullanma amaçlarının başında ürün tanıtımı ve kampanya/indirim bilgisi vermek geldiğini belirlemiştir. Çalışmada markaların takipçilerine yönelttiği ve fikirlerini paylaşmalarını istediği soruların çift yönlü iletişime katkıda bulunarak marka-tüketici bağını güçlendirdiği ortaya konmuştur. Çift yönlü güçlü iletişim sağlayan markaların, aynı zamanda tüketicilerin soru, şikâyet ve tavsiyelerini dikkate aldığı vurgulanmıştır. Çalışmada, markaların bu sayede geri bildirim alma imkânı bulduğu kaydedilmiştir. Böylece markaların tüketicide "değer görme" hissi uyandırarak marka bağlılığını güçlendirdiği savunulmaktadır (Akıncı Vural ve Okmeydan 2016, 80-81). Aslan Çetin ve Taşdemir ise yaptıkları çalışmada sosyal medya platformlarında düzenli paylaşımda bulunan ve tüketicilerine hızlı şekilde yanıt veren markaların sürdürülebilirlik sağladıklarını ortaya koymuştur. Buna göre aşırıya kaçmadan sade, öz ve marka imajına uygun düzenli paylaşımlar yapan markalar başarılı olmakta ve sürdürülebilirliği sağlamaktadır (Aslan Çetin ve Taşdemir 2018, 40).

\subsection{Literatür Taraması}

Sosyal medya pazarlaması ve Instagram'a ilişkin son yıllarda yapılan araştırmalardan bazıları Tablo-2'de sıralanmaktadır. 2013 ile 2020 yılları arasında sosyal medya pazarlamasında içerik yönetimi, tüketici ilişkileri yönetimi ve iletişim, Instagram'da tüketicilerin satın alma 
davranışı, sürdürülebilirlik, marka değeri, Instagram kullanma amaçları, marka iletişiminde Instagram kullanımı, sosyal medya platformlarının modaya ilişkin tüketici kararlarına etkisi, sosyal medya pazarlama faaliyetlerinin müşteri değerine etkisi gibi konularda yapılmış çeşitli araştırmalar yer almaktadır.

Tablo 2. Literatür Taramas1

\begin{tabular}{|c|c|c|}
\hline Çalışmayı Yapan & Çalışmanın Konusu & Çalışmanın Bulguları \\
\hline Özgen ve Doymuş, 2013 & $\begin{array}{l}\text { Sosyal medya pazarlamasında } \\
\text { farklılaştırıcı bir unsur olarak } \\
\text { içerik yönetimi }\end{array}$ & \begin{tabular}{llr} 
Markaların & sosyal medya & paylaşımları \\
üzerinden & rakiplerini analiz & edebileceği, \\
böylece kendi içeriklerini & geliştirip \\
zenginleştirerek & \multicolumn{2}{c}{ rakiplerinden } \\
farklılaşabilecekleri savunulmuştur.
\end{tabular} \\
\hline $\begin{array}{l}\text { Akıncı Vural ve } \\
\text { Okmeydan, } 2016\end{array}$ & $\begin{array}{l}\text { Sosyal medyada tüketici } \\
\text { ilişkileri yönetimi ve } \\
\text { iletişimin özellikleri }\end{array}$ & $\begin{array}{l}\text { Markaların takipçilerine yönelttiği ve fikirlerini } \\
\text { paylaşmalarını istediği soruların çift yönlü } \\
\text { iletişime katkıda bulunarak marka- tüketici } \\
\text { bağını güçlendirdiği ortaya konmuştur. }\end{array}$ \\
\hline $\begin{array}{c}\text { Yaşa Özeltürkay, } \\
\text { Bozyiğit ve Gülmez, } 2017\end{array}$ & $\begin{array}{l}\text { Instagram'dan alışveriş yapan } \\
\text { tüketicilerin satın alma } \\
\text { davranışları }\end{array}$ & $\begin{array}{l}\text { Tüketicilerin Instagram'da bir işletmeyi bilgi } \\
\text { almak amacıyla takip ettiği, platform } \\
\text { üzerinden çoğunlukla kıyafet, ayakkabı, } \\
\text { aksesuar ve saat satın alındığı belirlenmiştir. }\end{array}$ \\
\hline Aslan Çetin \& Taşdemir & $\begin{array}{c}\text { Sürdürülebilir sosyal medya } \\
\text { pazarlaması }\end{array}$ & $\begin{array}{l}\text { Sosyal medya platformlarında aşırıya } \\
\text { kaçmadan, sade, öz ve marka imajına uyan } \\
\text { düzenli paylaşımlar yapan ve tüketicilerine hızlı } \\
\text { şekilde yanıt veren markaların } \\
\text { sürdürülebilirlik sağladıkları ve başarılı olduğu } \\
\text { ortaya konmuştur. }\end{array}$ \\
\hline Khan, 2018 & $\begin{array}{l}\text { Instagram pazarlaması, marka } \\
\text { değeri ve tüketicinin markaya } \\
\text { yönelik davranışları } \\
\text { arasındaki ilişki }\end{array}$ & $\begin{array}{l}\text { Instagram pazarlamasının tek başına marka } \\
\text { bilinirliği oluşturma ve yeni tüketicilere } \\
\text { ulaşmaya yeterli olmayacağı ancak marka imajı } 1 \\
\text { oluşturma noktasında gittikçe öneminin arttığ } \\
\text { tespit edilmiştir. }\end{array}$ \\
\hline Yayla, 2018 & $\begin{array}{l}\text { Instagram kullanma } \\
\text { motivasyonları }\end{array}$ & $\begin{array}{l}\text { Kişilerin Instagram'1 } \\
\text { eğlence/alışkanlık, sosyal kaçış/rahatlama, } \\
\text { karar verme/bilgilenme, kişisel gelişim/kendini } \\
\text { ifade etme, arkadaşlık, sosyal etkileşim, } \\
\text { ekonomi, takip etme ve kişisel sunum } \\
\text { motivasyonlarıla kullandığı ortaya çıkmıştır. }\end{array}$ \\
\hline Garip, 2019 & $\begin{array}{l}\text { Instagram'ın marka } \\
\text { iletişiminde kullanımı }\end{array}$ & $\begin{array}{l}\text { Markaların paylaşımlarında yansıttığ } \text { marka } \\
\text { kişilikleri ile tüketicilerinin algısının uyumlu } \\
\text { olduğu tespit edilmiştir. }\end{array}$ \\
\hline Nash, 2019 & $\begin{array}{l}\text { Sosyal medya platformlarının } \\
\text { İngiltere'de perakende } \\
\text { sektöründe moda tüketici } \\
\text { kararlarına etkisi }\end{array}$ & $\begin{array}{l}\text { Sosyal medya kullanımı, tüketicilerin yüksek } \\
\text { sokak modası perakendecilerine ilişkin satın } \\
\text { alma kararını etkilemektedir. }\end{array}$ \\
\hline $\begin{array}{l}\text { Tack, Veirman ve } \\
\text { Hudders, } 2020\end{array}$ & $\begin{array}{l}\text { Sosyal medya pazarlama } \\
\text { faaliyetlerinin müşteri } \\
\text { değerine etkisi }\end{array}$ & $\begin{array}{l}\text { Modaya uygunluk, eğlence ve ağızdan ağıza } \\
\text { pazarlamanın müşteri marka değerini pozitif } \\
\text { yönde etkilediği tespit edilmiştir. }\end{array}$ \\
\hline
\end{tabular}

Sosyal medya alanında yapılan araştırmalar incelendiğinde sosyal medyanın, tüketici üzerindeki etkisi, sosyal medya araçlarından Instagram'ın marka ve tüketici iletişimindeki rolü, içerik yönetimi gibi konuların ön plana çıktığı görülmektedir. Özellikle tüketici ile olan iletişimin ve ilişkinin sosyal medyadaki içeriklerin yönetimi ile gerçekleştirildiğine ve sosyal medyanın, tüketiciler üzerindeki etkisine yönelik araştırmaların ön plana çıktığı belirlenmektedir. 


\section{Metodoloji}

Metodoloji başlığı altında araştırmanın amacı, kapsamı, kısıtları, veri toplama aracı ve araştırma bulgularının analizi başlıkları açıklanmaktadır.

\subsection{Araştırmanın Amacı ve Kapsamı}

$\mathrm{Bu}$ araştırmanın amacı fenomen pazarlamasında sosyal medyanın rolünün belirlenmesi ve moda sektörüne yönelik bir içerik analizinin gerçekleştirilmesidir. Çalışma; fenomen pazarlaması, sosyal medya kavramları ile moda sektöründe faaliyet gösteren fenomenleri kapsamaktadır.

\subsection{Evren ve Örneklem}

$\mathrm{Bu}$ çalışmanın evreni moda sektörü kapsamında Instagram'da faaliyet gösteren Türk ve yabancı fenomenlerden oluşmaktadır. Bu çalışma nitel bir araştırmadır. Nitel araştırmalar genellikle amaçı bir şekilde belirlenmiş az sayıda örneklemle yürütülmektedir. Nitel örneklem, bazen tek bir birey veya küçük bir grubu kapsayabilmektedir. (Strauss ve Corbin, 2014). Çalışmanın örneklemi moda sektöründe Instagram'da faaliyet gösteren iki Türk ve iki yabancı olmak üzere toplam dört kadın fenomenden oluşmaktadır. Bu dört fenomen, makro fenomen kategorisinde bulunmaları, marka etkileşimlerinin yüksek olması ve moda sektöründe faaliyet göstermeleri sebebi ile seçilmiştir. Bu çalışmanın nitel araştırma olması sebebi ile örneklem seçme yöntemi olarak ölçüt örneklem yöntemi kullanılmıştır. Ölçüt örneklem yöntemi, önceden belirlenmiş bir dizi ölçütü karşılayan bütün durumların çalışılmasıdır. Ölçüt, araştırmacı tarafından oluşturulabilir ya da daha önceden hazırlanmış ölçütler listesi kullanılabilir (Marshall ve Rossman 2014, Baltacı 2018). Örneklemin problemle ilgili olarak belirlenen niteliklere sahip kişiler, olaylar, nesneler ya da durumlardan oluşturulması şeklinde ifade edilebilir. Araştırma örnekleminin seçiminde; makro fenomen kategorisi kapsamında takipçi sayısı 500 binin üzerinde olma ve moda sektörüne yönelik ürün tanıtımlarında bulunma ölçütleri kullanılmıştır. Aynı zamanda araştırma bulgularının küresel çapta karşılaştırılabilmesi adına farklı ülkelerde faaliyet gösteren fenomenler örneklem kapsamına dahil edilmiştir. Bu ölçütler göz önünde bulundurularak oluşturulan araştırma örneklemi Türk fenomenlerden Rachel Araz Kiresepi ve Yasemin Ögün; yabanc1 fenomenlerden ise Annabelle Fleur ve Micah Giannelli olarak belirlenmiştir. Bu fenomenler, moda sektöründe 500 binin üzerinde takipçi sayısına sahip olması ve marka etkileşiminin yüksek olması sebebi ile seçilmiştir.

\subsection{Araştırmanın Kısıtları}

$\mathrm{Bu}$ çalışma, zaman ve bütçe kısıtları çerçevesinde gerçekleştirilmiştir. Bunun dışında araştırmanın moda sektörü üzerinde gerçekleştirilmesi ve sadece Instagram platformunda 
Öztek, M. Y., Yerden Karabıyık, N., Çolak, E., Sarı, E. / Journal of Yasar University, 2021, 16/62, 1053-1077

faaliyet gösteren dört fenomenin seçilmiş olması da çalışmanın diğer kısıtlarını oluşturmaktadır.

\subsection{Araştırma Yöntemi ve Veri Toplama Aracı}

$\mathrm{Bu}$ araştırmada nitel araştırma yöntemlerinden içerik analizi yöntemi kullanılmıştır. İçerik analizi, veriden onun içeriğine ilişkin tekrarlanabilir ve geçerli sonuçlar çıkarmak üzere kullanılan bir araştırma tekniğidir (Krippendorff 1980, 25). Bir başka tanıma göre içerik analizi, metinden geçerli çıkarımlar yapmak için bir dizi prosedür kullanılan bir araştırma tekniği olarak ifade edilebilir. Bu çıkarımlar mesajın göndericileri, mesajın kendisi veya mesajın izleyicileri hakkındadır. Nitel ve nicel içerik analizi olmak üzere iki farklı kullanım alanı söz konusudur. Nicel içerik analizi, nesnellik/özneler arasılık, güvenilirlik, geçerlilik ve genelleştirilebilirlik standartlarına uygun olarak verilerin sayısallaştırılması sonucunda araştırma bulgularının yorumlanmasına dayanmaktadır. Nitel içerik analizi ise tüm yazılı, sözlü ve görsel içeriği ifade etmektedir (Altheide ve Schneider 2013). Schreier (2012) nitel içerik analizinin özelliklerini yorumlayıcı, doğalcı, durumsal, dönüşlü, ortaya çıkan, esnekliğe sahip, tümevarımcı, vaka odaklı ve geçerliliğe vurgu yapan özellikler olarak tanımlamaktadır. Yöntem, bir metindeki tematik kalıpların (mesaj veya mesaj dizisi) tanımlanmasına dayanmaktadır.

Moda sektöründe ürün tanıtımlarının içerik analizi, seçilen fenomenlerin Instagram paylaşımlarının analizi yapılarak gerçekleştirilmektedir. Çalışma örneklemi; seçilen fenomenlerin 2019 yılının Ekim, Kasım ve Aralık olmak üzere 3 aylık dönemde yaptıkları moda sektörüne ilişkin toplam 386 ürün tanıtımından oluşmaktadır. Paylaşımların içerik analizi; gönderi içeriği, gönderi şekli, ürün türü, marka kökeni, marka isimleri, görsel içindeki yer, görünürlük, kamera açısl, ürünün sergilenme biçimi ve görsel yoğunluk olmak üzere 10 ana başlık altında incelenmiştir.

- Gönderi içeriğ i; kişisel, moda ürün yerleştirme ve diğer ürün yerleştirme başlıklarından oluşmaktadır.

- Gönderi şekli; görsel, sesli video ve sessiz video başlıklarını içermektedir.

- Ürün türü; kıyafet, ayakkabı, çanta ve aksesuar başlıklarını barındırmaktadır.

- Marka kökeni; yabanc1 marka, yerli marka ve fenomenin kendi markası kategorilerinden oluşmaktadır.

- Marka isimleri; fenomenlerin ilgili dönemde incelenen paylaşımlarında 10 veya daha fazla kez ürün tanıtımı yapılan yerli, yabancı ve kendi markalarının listesidir.

- Görsel içindeki yer; ürünün ön veya arka planda olması şeklinde belirlenmektedir.

- Görünürlük; görünürlük ürünün yakın veya uzak çekimle sunulmasını kapsamaktadır. 
- Kamera açısı; ürünün merkezde olup olmamasını ifade etmektedir.

- Görsel yoğunluk; ürün yerleştirmenin sade veya yoğun olmasını, herhangi bir dekor veya görselle desteklenip desteklenmemesini ifade etmektedir.

- Ürünün sergilenme biçimi; gönderide yalnızca ürün veya paketinin sergilendiği “ürün/paket”, yalnızca metinde ürün türünden bahsedilen "metin” veya markanın etiketlendiği ve internet sitesi bağlantısının paylaşıldı̆̆ "reklam” desteğinin bulunup bulunmadığını ifade etmektedir.

Araştırmada yer alan fenomenler hesap türlerine göre "Yüksek Moda" ve "Sokak Modası" olmak üzere ayrılmıştır. Bu çalışma nitel bir içerik analizidir. Yapılan bu çalışmayla seçilen dört Instagram fenomeninin belli bir zaman aralığında moda sektöründe ürün tanıtımı yaparken sergiledikleri eğilimler tespit edilmeye çalışılmıştır.

\subsection{Araştırma Bulguları ve Analizi}

Araştırmanın örneklemi için seçilen Instagram fenomenleri Annabelle Fleur, Micah Giannelli, Rachel Araz Kiresepi ve Yasemin Ögün'dür. 5 Haziran 2020 itibariyle Annabelle Fleur'un 801 bin takipçisi ve 4237 paylaşımı bulunmaktadır. Bu paylaşımlardan 72 tanesi 1 Ekim-31 Aralık 2019 aralığında yapılmıştır. İçerik analizi, 72 paylaşımdan moda ürün tanıtımı içeren 63 tanesinde yukarıda belirlenen kriterlere göre yapılmıştır. Diğer yabancı fenomen Micah Giannelli’nin 1 milyon takipçisi ve 3961 paylaşımı bulunmaktadır. Fenomenin belirlenen tarih aralığında 93 paylaşımı bulunmaktadır. İçerik analizinde 93 paylaşımdan moda ürün tanıtımı içeren 89 tanesi incelenmiştir. Türk fenomen Rachel Araz Kiresepi'nin 643 bin takipçisi, 4309 paylaşımı vardır. Belirlenen tarih aralığındaki 158 paylaşımdan moda ürün tanıtımı içeren 84 tanesi içerik analizinde incelenmiştir. Diğer Türk fenomen Yasemin Ögün'ün 726 bin takipçisi ve 16.200'den fazla paylaşımı bulunmaktadır. Paylaşımlardan 278 tanesi belirlenen tarih aralığında yer almaktadır. Bu paylaşımlardan moda ürün yerleştirme içeren 150 tanesi içerik analizi çerçevesinde incelenmiştir. Toplamda seçilen dört kadın fenomenin 1 Ekim 2019 ile 31 Aralık 2019 tarihleri arasındaki 601 paylaşımından moda ürün yerleştirme içeren 386 tanesi belirlenen 10 kategoriye göre incelenmiş ve araştırma bulguları analiz edilmiştir. 
Tablo 3. Fenomenlerin Paylaşımlarına Yönelik İçerik Analizi Sonuçları

\begin{tabular}{|c|c|c|}
\hline KATEGORİ & FREKANS & YÜZDE \\
\hline \multicolumn{3}{|l|}{ Fenomenin Hesap Türü } \\
\hline Yüksek Moda & 3 & $\% 75$ \\
\hline Sokak Modas1 & 1 & $\% 25$ \\
\hline \multicolumn{3}{|l|}{ Gönderi İçeriği } \\
\hline Kişisel & 179 & $\% 29,78$ \\
\hline Moda Ürün Yerleştirme & 386 & $\% 64,23$ \\
\hline Diğer Ürün Yerleştirme & 36 & $\% 5,99$ \\
\hline \multicolumn{3}{|l|}{ Gönderi Şekli } \\
\hline Görsel & 367 & $\% 95,08$ \\
\hline Sesli Video & 10 & $\% 2,59$ \\
\hline Sessiz Video & 9 & $\% 2,33$ \\
\hline \multicolumn{3}{|l|}{ Ürün Türü } \\
\hline Kiyafet & 312 & $\% 45,22$ \\
\hline Ayakkabı & 164 & $\% 23,77$ \\
\hline Çanta & 129 & $\% 18,70$ \\
\hline Aksesuar & 85 & $\% 12,31$ \\
\hline \multicolumn{3}{|l|}{ Marka Kökeni } \\
\hline Yabancı Marka & 333 & $\% 67,55$ \\
\hline Yerli Marka & 76 & $\% 15,42$ \\
\hline Kendi Markası & 84 & $\% 17,03$ \\
\hline \multicolumn{3}{|l|}{ Görsel İçindeki Yeri } \\
\hline Ön Planda & 372 & $\% 96,38$ \\
\hline Arka Planda & 14 & $\% 3,62$ \\
\hline \multicolumn{3}{|l|}{ Görünürlük } \\
\hline Yakın Çekim & 186 & $\% 48,19$ \\
\hline Uzak Çekim & 200 & $\% 51,81$ \\
\hline \multicolumn{3}{|l|}{ Kamera Açısı } \\
\hline Ürün Merkezde & 357 & $\% 90,38$ \\
\hline Ürün Merkezde Değil & 29 & $\% 9,62$ \\
\hline \multicolumn{3}{|l|}{ Ürünü Sergileme Biçimi } \\
\hline Ürün/Paket & 164 & $\% 42,49$ \\
\hline Reklam & 181 & $\% 46,89$ \\
\hline Metin & 41 & $\% 10,62$ \\
\hline \multicolumn{3}{|l|}{ Görsel Yoğunluk } \\
\hline Sade & 221 & $\% 57,26$ \\
\hline Yoğun & 165 & $\% 42,74$ \\
\hline
\end{tabular}

Araştırmada Annabelle Fleur, Micah Giannelli, Rachel Araz Kiresepi ve Yasemin Ögün'ün Ekim-Aralık 2019 tarih aralığında yaptıkları 601 paylaşım incelendiğinde, Annabelle Fleur, Micah Giannelli ve Rachel Araz Kiresepi'nin yüksek moda türünde paylaşımlar yaptığı, Yasemin Ögün'ün ise sokak modası türünde paylaşımlar yaptığı görülmüştür.

Araştırmaya konu olan fenomenler, gönderi içeriği açısından değerlendirildiğinde 386 adet moda ürün yerleştirmeye yönelik paylaşımda bulunduğu, 179 adet ise kişisel gönderi içeriği paylaştığı görülmektedir. $\mathrm{Bu}$ bulgular fenomenlerin, gönderi içeriğinde moda ürünlerine yönelik paylaşımlar yaptığını ve moda ürünlerini, ürün/marka yerleştirme yolu ile paylaşmayı daha fazla tercih ettiğini göstermektedir. Bu sebep ile araştırmada yalnızca moda ürün yerleştirme içeriğine sahip paylaşımlar analiz edilmektedir. Fenomenlerin paylaşımları gönderi şekline göre incelendiğinde 367 (\%95) adet görsel paylaşımın yapıldığ1 

görülmektedir. Diğer paylaşımların ise 10 adet $(\% 2,59)$ sesli video ve 9 adet $(\% 2,33)$ sessiz video şeklinde yapıldığı ortaya çıkmaktadır. Bu sonuç, görsel paylaşımların, sesli ya da sessiz video paylaşımlarına göre çok daha sıklıkla tercih edildiğini ortaya koymaktadır. Aynı zamanda takipçiler açısından değerlendirildiğinde yine görsel paylaşımların, işitsel paylaşımlara göre daha fazla takip edildiği ifade edilebilir. Bu çalışmada yapılan içerik analizine göre 312 adet $(\% 45,22)$ kıyafet, 164 adet $(\% 23,77)$ ayakkab1, 129 adet $(\% 18,70)$ adet çanta ve sadece 85 adet $(\% 12,31)$ aksesuar türünde ürün paylaşımının yapıldığı ortaya çıkmaktadır. Bu sonuç, moda fenomenlerinin ağırlıklı olarak kıyafet ve ayakkabı tanıtımı yaptıklarını göstermektedir. Yapılan paylaşımlar, marka kökenine göre incelendiğinde 333 adet $(\% 67,55)$ yabanı marka paylaşımının, $84(\% 17,03)$ adet kendi markalarının, 76 $(\% 15,42)$ adet ise yerli marka paylaşımlarının olduğunu göstermektedir. $\mathrm{Bu}$ bulgu, fenomenlerin en fazla uluslararası markalara yönelik paylaşımları, sonrasında ise kendi markalarını içeren paylaşımları tercih ettiklerini göstermektedir. Bunun dişında paylaşılan ürünün görsel içindeki yeri analiz edildiğinde 386 paylaşımın 372'sinde tanıtılan ürünün ön planda, yalnızca 14'ünde arka planda olduğu belirlenmiştir. Görünürlük kriterine göre 200 paylaşımın $(\% 51,81)$ uzak çekim, 186 paylaşımın $(48,19)$ ise yakın çekim olduğu görülmektedir. Ürün yerleştirme paylaşımlarında ürünlerin kamera açısına göre $357(\% 90,38)$ paylaşımda tanıtılan ürün kameranın merkezinde, 29'unda $(\% 9,62)$ ise merkez dışında bir konumda yer almaktadır. Ürünün, fenomenler tarafından sergileme biçimi analiz edildiğinde 181 adet reklam türünde sergilemenin olduğu görülmektedir. Bu bulgu, ürün tanıtımında gönderi üzerinde ürünün markasının etiketlendiğini, internet sitesi bağlantısının da açıklama kısmına eklendiğini göstermektedir. Bu sonucu, 164 adet $(\% 42,49)$ ürün/paket ve 41 adet $(\% 10,62)$ metin türünde sergilemenin takip ettiği görülmektedir. $\mathrm{Bu}$ sonuç, fenomen pazarlamasında ürünlerin en fazla reklam yöntemi ile tanıtıldığını göstermektedir. Görsel yoğunluk kriterinde paylaşımlarda fazladan süs, arka plan veya dikkat dağıtıcı herhangi başka bir unsur olup olmadığı incelenmiştir. Buna göre 221 paylaşımda, tanıtılan ürünü ortaya çıkaracak sade paylaşımların tercih edildiği; 165 paylaşımda ise daha yoğun bir görsellik kullanıldığı sonucuna varılmıştır.

Yapılan bu içerik analizi sonuçlarına göre moda fenomenlerinin takipçilerini moda ürünlerin tanıtımı konusunda moda ürünleri kullanarak, sade bir sunum alanında moda ürününü reklam yöntemi ile tanıtarak etkilediğini göstermektedir. Bu çalışma fenomen pazarlaması alanında gerçekleştirilen önceki araştırmaları desteklemektedir. Fenomen pazarlaması alanında yapılan önceki araştırmalara göre fenomen pazarlaması, markaların, tüketicilerin dikkatini çekmek ve onları satın almaya yönlendirmek için onların doğal alanlarına girerek yönlendirmeyi gerçekleştiren yöntemlerden biri olarak ortaya koymaktadır 
(Eker vd. 2017, 23). Bu durum tüketicilerin dikkatinin çekilmesinde ve etkilenmesinde fenomen pazarlamasının etkisini ortaya koymaktadır. Bununla birlikte moda sektöründe mikro Instabloggerlar üzerinde yapılan bir başka araştırmaya göre ürün/marka yerleştirme düzeylerinin yüksek olduğu belirlenmiştir. Buna karşılık takipçiler ile etkileşim düzeyinin düşük olduğu, paylaşımlarını yoğun olarak görseller aracılığı ile gerçekleştirdiğini göstermektedir (Öztürk ve Şener 2018, 397). Bu sonuç, moda sektöründe mikro fenomenler ile makro fenomenlerin ürün/marka yerleştirme düzeylerinin birbirini desteklediğini göstermektedir. Bununla birlikte belirli bir konuda uzmanlığı olan fenomenlerin, tüketicileri marka hayranlığı ve satın alma niyeti açısından olumlu etkilediği sonucuna varılmaktadır (Trivedi ve Sama 2020, 115). Moda sektöründe yapılan bir araştırmaya göre Instagram'ın, moda sektöründe dürtüsel satın almayı en çok etkileyen sosyal medya olduğu görülmüştür. Bunun başlıca nedeni ise Instagram'ın markaların görsel yönünü tanıtmadaki gücü olarak açıklanmaktadır. Bu platformun özellikle kadın takipçilerin dürtüsel satın alımlarını derinden etkilediği; Instagram'ın moda ilhamı ve güncel trendler için bir platform olduğu ve moda sektöründe tüketici davranışında önemli bir değişikliğe yol açtı̆̆ 1 görülmektedir (Djafarova ve Bowes 2020, 7). Bu sonuçlar moda sektöründe Instagram platformunun ve Instagram aracılığ1 ile gerçekleştirilen fenomen pazarlamasının etkisinin büyüklüğünü ortaya koyarak yapılan bu çalışmayı destekler niteliktedir.

\section{Sonuç}

Dijitalleşmenin hızlı gelişimi birçok alanın yanı sıra reklam ve tanıtım alanlarında da etkili olmuş, birtakım değişikliklere ve yeniliklere olanak sağlamıştır. Sosyal medyanın, tüketicilerin günlük yaşantılarının bir parçası haline gelmesi, işletmelere ürünlerinin tanıtımı ve pazarlanması için yeni firsat alanları sunmaktadır. Bu firsat alanlarından biri de fenomen pazarlamasıdır. Her geçen gün daha fazla takipçiye ulaşan fenomenler bu sayede farklı markaların ürünlerini rahatlıkla tanıtmaktadır. $\mathrm{Bu}$ sebeple bu çalışmada fenomen pazarlamasının sosyal medyadaki rolünün moda sektöründe incelenmesi amaçlanmıştır.

Çalışmada fenomen pazarlaması ve sosyal medya alanlarındaki literatür taranmış, ardından moda sektöründeki fenomenlerin paylaşımları nitel araştırma yöntemlerinden içerik analizi yöntemiyle incelenmiştir. Araştırmada seçilen iki Türk, iki yabancı fenomenin paylaşımları, içerik analizi ile incelenmiştir. Paylaşımların içerik analizi; gönderi içeriği, gönderi şekli, ürün türü, marka kökeni, marka isimleri, görsel içindeki yer, görünürlük, kamera açısı, ürünün sergilenme biçimi ve görsel yoğunluk olmak üzere 10 ana başl1k altında incelenmiştir. Araştırmada seçilen fenomenlerin çoğunluğunun hesap türü, yüksek moda türündedir. Paylaşımlarda gönderi içeriği açısından en çok moda ürünleri kullanılmıştır. 
Bununla birlikte fenomenlerin gönderilerinin büyük çoğunluğunda görsel paylaşımları tercih ettiği, ürün türü olarak ise çoğunluğun kıyafet, ardından ayakkabı ürünlerini paylaştığı görülmektedir. Yine araştırmada seçilen fenomenlerin büyük çoğunluğunun yurt dışı kökenli markaların ürünlerini tanıttığı ve ürünlerin ön planda tutulduğu tespit edilmiştir. Fenomenlerin görünürlük açısından büyük çoğunluğunun uzak çekimi tercih ettikleri ve ürünü merkezde çektikleri sonucuna varılmaktadır. Ürünü sergileme biçiminde reklam ve ürün/paket ağırlıklı sergileme biçiminin olduğu, görsel yoğunluk noktasında ise sadeliğin daha fazla kullanıldığı ortaya çıkmıştır.

$\mathrm{Bu}$ araştırma, doğası gereği sonuçların genellenebilirliği açısından kısıtlı bilgi sağlamaktadır. Ancak araştırmada üç aylık bir süreçte moda gibi hızlı tüketimin bulunduğu bir sektörde ürün yerleştirme paylaşımları, incelenen Türk ve yabancı fenomenlerin takipçi sayılarının yüksek olması sebebiyle sosyal medyada etkili birer aktör olarak yer almaktadır. Bu kişiler, 500 binin üzerinde olan yüksek takipçi sayılarıyla yeni keşfedilen bir faaliyet alanı olan fenomen pazarlamasına ilişkin birer örnek teşkil etmektedir. Dolayısıyla bu çalışmada elde edilen bulgular, Instagram platformu üzerinde moda alanında faaliyet gösteren fenomenlerin ürün yerleştirme biçimlerindeki genel eğilime ilişkin somut bir fikir oluşturmaktadır.

Fenomen pazarlaması alanında yapılan geçmiş araştırmalar incelendiğinde özellikle moda sektöründe ürün tanıtımında fenomenlerin oldukça etkili olduğu, ürün görsellerinin ön planda tutulduğu, sade ve geniş açı çekimlerine yer verildiği, özellikle kadınlar tarafından dürtüsel alışverişlerin yapılmasını desteklediği, fenomenin etki alanına göre tüketicileri satın almaya yönlendirdiği gibi sonuçlara varıldığg görülmektedir. Yapılan bu çalışmanın moda sektöründe fenomen pazarlaması üzerine gerçekleştirilen önceki çalışmaları desteklediği, seçilen moda fenomenlerinin ürün yerleştirme, ürünü ön planda tutma, sade bir görsel sunum sergileme, ağırlıklı olarak yabancı markaların tanıtımını gerçekleştirme ve reklam yöntemini kullanmaları yönünde faaliyetlerde bulunduğunu göstermektedir.

$\mathrm{Bu}$ araştırmanın sonucunda moda sektöründeki işletmelerin ya da bireysel uygulamacıların, kişisel gönderilerden çok moda ürün gönderilerini paylaşmaları, görsel paylaşımlarda bulunmaları, ürünün görsel içindeki yerinin ön planda tutulması, uzak plan çekimlerin yapılması, ürünün merkezde olması ve görsel yoğunluk açısından sadeliğin kullanılmasının takipçilere daha doğru bir şekilde ulaşılacağını göstermektedir. Özellikle moda sektöründeki işletmelerin fenomen pazarlamasını kullanmaları, hedef kitleleri ile sürdürülebilir bir iletişim açısından oldukça yararlı görülmektedir.

Gelecek çalışmalarda daha geniş kapsamlı bir örneklem ve veri setinden yararlanılmasının uygun olabileceği düşünülmektedir. Öte yandan gelecekte yapılacak 
Öztek, M. Y., Yerden Karabıyık, N., Çolak, E., Sarı, E. / Journal of Yasar University, 2021, 16/62, 1053-1077 çalışmalar ürün tanıtımına ilişkin etkileşim ve paylaşım oranları gibi sayısal verilerin elde edilebileceği çeşitli sosyal medya metriklerini de değerlendirerek bu çalışmada ortaya çıkan eğilimleri test edebilirler. 


\section{KAYNAKÇA}

Abidin, Crystal. 2016. "Visibility labour: Engaging with Influencers' Fashion Brands and \#OOTD Advertorial Campaigns on Instagram." Media International Australia 16, no. 1: 86-100.

Akıncı Vural, Beril ve Cudi Kaan Okmeydan. 2016. "Türkiye'deki Moda Markalarının Sosyal Medya Üzerinden Hedef Kitleleri ile Kurdukları İletişim ve Sosyal Müşteri İlişkileri Yönetimi.” Akdeniz İletişim Dergisi (25): 64-83. Doi: https://doi.org/10.31123/akil.438524.

Aktaş, Aysel ve Gül Şener. 2019. "Nüfuz Pazarlamasında (Influencer Marketing) Mesaj Stratejileri." Erciyes İletişim Dergisi 6 (1): 399-422.

Altheide, David L. ve Christoper J. Schneider. 2013. Qualitative Media Analysis. 2nd Edition. Thousand Oaks, CA: Sage.

Armağan, Ece Aksu ve Mehmet Can Doğaner. 2019. "Fenomen Pazarlaması: Youtube Güzellik Vloggerları Üzerine Bir Araştırma." 1st International Congress of Political Economic and Financial Analysis: 223234.

Aslan Çetin, Filiz ve Nezefet Havva Taşdemir . 2018. "Sürdürülebilir Sosyal Medya Pazarl aması ve Markaların Sosyal Medyada Sürdürülebilirliğe Karşı Tutumu .” Journal of Institute of Economic Development and Social Researches 4 (8): 31-42.

Baltacı, Ali. 2018. "Nitel Araştırmalarda Örnekleme Yöntemleri ve Örnek Hacmi Sorunsalı Üzerine Kavramsal Bir İnceleme". Bitlis Eren Üniversitesi Sosyal Bilimler Enstitüsü Dergisi 7 (1): 231-274.

Booth, David ve Corey Koberg. 2012. Display Advertising: An Hour a Day. Indianapolis, IN: John Wiley \& Sons Incorporated.

Business Insider. 2020. "Influencer Marketing: State of the Social Media Influencer Market in 2020" https://www.businessinsider.com/influencer-marketing-report Erişim: 28.05.2020

Campbell, Colin, and Justine Rapp Farrell. 2020. "More than meets the eye: The functional components underlying influencer marketing". Business Horizons 63(4) : 469-479.

Can, Serap ve Konur Alp Koz. 2018. "Sosyal Medyada Tüketici Onaylı Pazarlama: Instagram Örneği.” eKurgu, Anadolu Üniversitesi İletişim Bilimleri Fakültesi Uluslararası Hakemli Dergisi 26 (3): 444-457.

Childers, Courtney Carpenter, Laura L. Lemon ve Mariea G. Hoy. 2019. "\# Sponsored\# Ad: Agency Perspective on Influencer Marketing Campaigns." Journal of Current Issues \& Research in Advertising 40 (3): 258274.

Close, Angelina G. 2012. Online Consumer Behavior: Theory and Research in Social Media, Advertising and etail. Routledge. https://ebookcentral.proquest.com

Collier, Martha. 2012. Social Media Commerce for Dummies. John Wiley \& Sons. ProQuest Ebook Central, http://ebookcentral.proquest.com/lib/gsutr/detail.action?docID=875837.

Cuevas, Leslie M., Sze Man Chong, and Heejin Lim. 2020. "Influencer marketing: Social media influencers as human brands attaching to followers and yielding positive marketing results by fulfilling needs." Journal of Retailing and Consumer Services 55 (2020): 102133, 1-11.

Çetin, Filiz Aslan ve Neval Öziç. 2020. "Bütünleşik Pazarlama İletişiminde Instagram Fenomenlerinin Satın Almaya Etkisi.” İşletme Araştırmaları Dergisi 12 (1): 157-172.

De Veirman, Marijke, Veroline Cauberghe ve Liselot Hudders. 2017. "Marketing Through Instagram Influencers: The Impact of Number of Followers and Product Divergence on Brand Attitude." International Journal of Advertising 36 (5): 798-828.

Djafarova, Elmira ve Tamar Bowes. 2020. “'Instagram made Me buy it': Generation Z impulse purchases in fashion industry". Journal of Retailing and Consumer Services, 102345.

Dwivedi, Y. K., Ismagilova, E., Hughes, D. L., Carlson, J., Filieri, R., Jacobson, J., ... \& Wang, Y. 2020. "Setting the future of digital and social media marketing research: Perspectives and research propositions". International Journal of Information Management, 102168.

EKER, Merve, Müjde BAYINDIR, Seda BÜKTEL ve Kamer YILMAZ. 2017. "Influencer'ın Hatırı Kaç Yıl Sürer", Campaign Dergisi, 69, s.22-24.

Evans, Dave. 2008. Social Media Marketing: An Hour a Day. Indianapolis, IN: Wiley Publishing, Inc.

Fertik, Michael. 2020. Why is influencer marketing such A big deal right now? Forbes. URL. https://www.forbes.com/sites/michaelfertik/2020/07/02/why-is-influencer-marketing-such-a-big-dealright-now/?sh=650fb55475f3. Erişim tarihi: 03.09.2020.

Garip, Sezen. 2019. “Instagram'ın Marka İletişiminde Kullanımı: Marka Kişiliği Göstergeleri Açısından Bir 
Değerlendirme." Uluslararası Sosyal Bilimler Akademik Araştırmalar Dergisi 3 (2): 11-22.

Gümüş, Niyazi. 2020. "Z Kuşağı tüketicilerin satın alma karar tarzlarının incelenmesi." Journal of Yaşar University 15.58 (2020): 381-396.

Hemann, Chuck ve Ken Burbary. 2013. Digital Marketing Analytics Making Sense of Consumer Data in a Digital World. Indianapolis: IN, Que Publishing.

Jin, S. Venus, Aziz Muqaddam ve Ehri Ryu. 2019. "Instafamous and Social Media Influencer Marketing." Marketing Intelligence \& Planning 37 (5): 567-579.

Khan, S. 2018. "Instagram as a Marketing Tool for Luxury Brands." International Journal of Management and Business Research 8 (2): 120-126.

Kim, Angella J. ve Eunju Ko. 2012. "Do Social Media Marketing Activities Enhance Customer Equity? An Empirical Study of Luxury Fashion Brand.” Journal of Business Research 65 (10): 1480-1486.

Kotler, Philip ve Gary Armstrong. 2011. Principles of Marketing. 14th Edition. Upple Saddle River, NJ: Prentice Hall.

Krippendorff, Klaus. 1980. Content Analysis: An Introduction to Its Methodology. London, UK: Sage Publications, Inc.

Lou, Chen ve Shupei Yuan. 2019. "Influencer Marketing: How Message Value and Credibility Affect Consumer Trust Of Branded Content on Social Media." Journal of Interactive Advertising 19 (1): 58-73.

Marshall, Catherine ve Gretchen B. Rossman. 2014. Designing Qualitative Research. New York, NY: Sage Publications, Inc.

Marwick, Alice E. 2015. "Status Update-Celebrity, Publicity, and Branding in the Social Media Age." New Haven, CT: Yale University Press, 368 PP, ISBN: 9780300176728.

Mashhadani, Yasameen Thaer. A. Al. 2019. "The Impact of Trust on Social Media's Influencers and the Effect of Influencer's Discount Codes on the Consumer Purchase Involvement". Kadir Has University School of Graduate Studies, Yayınlanmamış Yüksek Lisans Tezi.

Mohammadian, Mahmoud ve Marjan Mohammadreza. 2012. "Identify The Success Factors of Social Media (Marketing Perspective)." International Business and Management 4 (2): 58-66.

Nash, Jill. 2019. "Exploring How Social Media Platforms Influence Fashion Consumer Decisions in the UK Retail Sector." Journal of Fashion Marketing and Management: An International Journal 23 (1): 82 103. https://doi.org/10.1108/jfmm-01-2018-0012.

Örs, Müge. 2018. "İnternet Fenomenlerini Neden Takip Ediyoruz? Tüketici-Fenomen İlişkisini Güçlendiren Nedenlerin Ampirik Bir Çalışma ile Değerlendirilmesi.” İşletme Araştırmaları Dergisi 10 (4): 187-209.

Özgen, Ebru, and Hüsnur Doymuş. 2013. "Sosyal Medya Pazarlamasında Farklılaştırıcı Bir Unsur Olarak İçerik Yönetimi Konusuna İletişimsel Bir Yaklaşım.” Online Academic Journal of Information Technology 4 (11): 91-103.

Öztürk, E., \& Şener, G. 2018. Modada nüfuz pazarlaması: Mikro instabloggerların ürün yerleştirme uygulamaları. Selçuk İletişim, 11(1), 382-412.

Purwaningwulan, Melly Maulin, Asep Suryana, Uud ud Wahyudin, and Susanne Susanne Dida. 2018. "The Uniqueness of Influencer Marketing in The Indonesian Muslim Fashion Industry on Digital Marketing Communication Era." International Conference on Business, Economic, Social Science and Humanities. Atlantis Press.

Purwar, Shristi. 2019. "Digital Marketing: An Effective Tool of Fashion Marketing." 10th International Conference on Digital Strategies for Organizational Success, 992-997. doi: https://dx.doi.org/10.2139/ssrn.3318992

Robson, Garry ve Malgorzata Zachara. 2014. Digital Diversities: Social Media and İntercultural Experience. UK: Cambridge Scholars Publishing.

Sarıtaş, Ayşe. 2018. "Sosyal Medya Reklamlarında Fenomen Kullanımı ve Reklam İzleme Tercihi." The Journal of International Scientific Researches 3 (4): 62-74.

Schreier, Margrit. 2014. "Varianten Qualitativer Inhaltsanalyse: Ein Wegweiser im Dickicht der Begrifflichkeiten." Forum Qualitative Sozialforschung/Forum: Qualitative Social Research 15 (1): 1-27.

Sönmez, Ebru ve Hatun Boztepe Taşkıran. 2019. "Sosyal Medya Fenomenlerinin Tüketicilerin Marka Tercihine Etkisi: Kozmetik Markaları Üzerine Bir Araştırma." İNIF E-Dergi 4 (2): 111-132.

Spry, Amanda, Ravi Pappu ve T. Bettina Cornwell. 2011. "Celebrity Endorsement, Brand Credibility and Brand Equity." European Journal of Marketing 45 (6): 882-909.

Statista. (2020a). Global digital population as of October 2020. Available at https://www. 
statista.com/statistics/617136/digital-population-worldwide/ . Erişim Tarihi: 25.01.2020.

Statista. (2020b). Number of social network users worldwide from 2017 to 2025 https://www.statista.com/statistics/617136/digital-population-worldwide/ . Erişim:25.01.2021

Statista. (2020c). Instagram: number of global users 2016-2023, https://www.statista.com/statistics/183585/instagram-number-of-global-users/, Erişim: 12.12.2020

Sterne, Jim. 2010. Social Media Metrics: How to Measure and Optimize Your Marketing Investment. Hoboken, NJ: John Wiley \& Sons, Inc.

Strauss, Anselm ve Juliet Corbin. 2014. Basics of Qualitative Research: Techniques and Procedures for Developing Grounded Theory. 4th Edition. Thousand Oaks, CA: SAGE Publications, Inc.

Sudha, M. ve Sheena, K. 2017. "Impact of Influencers in Consumer Decision Process: The Fashion Industry." SCMS Journal of Indian Management 14 (3): 14-30.

Sütçü, C. S., Aytekin, Ç., Kara, T., Akyazı, E., Dilmen, N. E., \& Değerli, B. . 2014. Jetfighter down! predicting opinions with twitter and the role of social media in turkey within context of attribute agenda-setting theory.

Şener, Gül, Eda Öztürk ve H. Kemal Suher. 2019. "Nüfuzumu Kullanırken Ben: Türkiye'deki Moda Instabloggerlarının Ürün Yerleştirme Uygulamaları Üzerine bir İçerik Analizi.” Anadolu Üniversitesi Sosyal Bilimler Dergisi 19 (2): 415-436.

Tack, Ineke, Marijke De Veirman ve Liselot Hudders. 2020. "Building a Luxury Brand on Instagram: The Case of Delvaux." Marché et Organisations 37 (1): 55-71.

Teo, Li Xin, Ho Keat Leng ve Yi Xian Philip Phua. 2018. "Marketing on Instagram: Social influence and image quality on perception of quality and purchase intention." International Journal of Sports Marketing and Sponsorship 20 (2): 321-332.

Trivedi, Jay ve Ramzan Sama. 2020. The effect of influencer marketing on consumers' brand admiration and online purchase intentions: An emerging market perspective. Journal of Internet Commerce, 19(1), 103124.

Tuten, Tracy L. 2008. Advertising 2.0: Social Media Marketing in A Web 2.0 World. USA: Praeger Publishers.

Uydac1, M. 2004. Pazarlamada Elektronik Posta Kullanimi. Ege Akademik Bakış Dergisi, 4(1), 79-84.

Veissi, Iman. 2017. "Influencer Marketing on Instagram". Haaga-Helia University of Applied Sciences. Yayınlanmamıș Lisans Tezi.

Vyatkina, O.L. 2020. "The Impact of Influencer Marketing on The Global Economy". II International Scientific Conference GCPMED 2019 "Global Challenges and Prospects of the Modern Economic Development", European Proceedings of Social and Behavioural Sciences EpSBS, e-ISSN: 2357-1330.

Weinberg, Tamar. 2009. The New Community Rules: Marketing on the Social Web. USA: O'reilly Media Inc.

Wiedmann, Klaus-Peter, Nadine Hennigs ve Sascha Langner. 2010. "Spreading the Word of Fashion: Identifying Social Influencers in Fashion Marketing.” Journal of Global Fashion Marketing 1 (3): 142-153.

Wiedmann, Klaus-Peter, Nadine Hennigs ve Sascha Langner. 2010. "Spreading the Word of Fashion: Identifying Social Influencers in Fashion Marketing." Journal of Global Fashion Marketing 1 (3): 142-153.

Woods, Steven. 2016. "Sponsored: The Emergence of Influencer Marketing." School of Advertising \& Public Relations. University of Tennessee, Yayınlanmamış Lisans Tezi.

Yaşa Özeltürkay, Eda, Sezen Bozyiğit ve Murat Gülmez . 2017. "Instagram'dan Alışveriş Yapan Tüketicilerin Satın Alma Davranışları: Keşifsel Bir Çalışma.” Marmara Üniversitesi Öneri Dergisi 12 (48): 175-198. Doi: 10.14783/maruoneri.vi.331668.

Yayla, Hatice Mine. 2018. "Kullanımlar ve Doyumlar Bağlamında Dokuz Eylül Üniversitesi Güzel Sanatlar Fakültesi Öğrencilerinin Sosyal Medya Kullanımı: Instagram Örneği.” Selçuk İletişim 11 (1): 40-65.

Yılmazsoy, Burak. 2019. "Sosyal Ağların Pazarlama Üzerindeki Etkileri: Instagram Örneği." Anemon Muş Alparslan Üniversitesi Sosyal Bilimler Dergisi 7 (1): 49- 58.

Zimmerman, Jan ve Deborah Ng. 2017. Social Media Marketing All-in-One For Dummies. Hoboken, NJ: John Wiley \& Sons, Inc. 